\title{
IMPLEMENTATION OF SCIENTIFIC INTEGRATION CONCEPT MONITORING AND EVALUATION ON THE PESANTREN LEARNING CURRICULUM
}

\author{
Reni Nuraeni ${ }^{1}$, Irawan Irawan ${ }^{2}$ \\ Islamic Educational Management Department, Universitas Islam Negeri Sunan Gunung Djati \\ Bandung, Indonesia \\ Email: reni.nur2801@gmail.com¹, irawan@uinsgd.ac.id ${ }^{2}$
}

Received: May 2021

DOI: http://doi.org/10.33650/al-tanzim.v5i2. 2186 Accepted: July 2021

Published: August 2021

\begin{abstract}
:
This study aims to determine the results of monitoring and evaluation of the implementation of curriculum integration carried out by an Islamic educational institution in Islamic boarding schools. The research was conducted at the Baitul Fikri Arcamanik Modern Islamic Boarding School in Bandung. The study uses a qualitative approach with the CIPO evaluation technique developed through observation and data collection with documentary data and structured interviews with rating-scale techniques. The results showed that the percentage value of the application of the concept of integration was in line with the results obtained with students' summative evaluation value data. The data on the application of the lowest integration concept is in Mathematics with a percentage of $55 \%$, and the average summative value of students is 73, while the highest data on the application of the concept of integration is in PJOK subjects with a percentage of $77 \%$ and the average summative score of 81 students.
\end{abstract}

Keywords: Monitoring, Evaluation of Scientific Integration, Pesantren, Curriculum

\begin{abstract}
Abstrak:
Penelitian ini bertujuan untuk mengetahui tentang hasil monitoring dan evaluasi dari penerapan integrasi kurikulum yang dilakukan oleh sebuah lembaga pendidikan Islam di pondok pesantren. Penelitian dilakukan di Pondok Pesantren Modern Baitul Fikri Arcamanik Kota Bandung. Penelitian menggunakan pendekatan kualitatif dengan teknik evaluasi CIPO yang dikembangkan melalui observasi dan pengumpulan data dengan data documentary dan wawancara terstruktur dengan teknik rating-scale. Hasil penelitian menunjukkan bahwa nilai prosentase penerapan konsep integrasi sejalan dengan hasil yang didapatkan dengan data nilai evaluasi sumatif santri. Data penerapan konsep integrasi terendah terdapat pada mata pelajaran Matematika dengan jumlah prosentase $55 \%$ dan nilai rata-rata sumatif santri 73, sedangkan data penerapan konsep integrasi tertinggi ada pada mata pelajaran PJOK dengan jumlah prosentase $77 \%$ dan nilai rata-rata sumatif santri 81 .
\end{abstract}

Kata Kunci: Monitoring, Evaluasi, Integrasi keilmuan, Kurikulum, Pesantren 


\section{INTRODUCTION}

Education is the most important thing for the progress of a nation. If a country has a good quality education, it will undoubtedly affect the nation's generation's quality. The achievement of the objectives of a learning process is the key to success. Education in the current era of globalization is a challenge for an educational institution, including Pesantren, to face all the changes. Therefore, monitoring and evaluation activities are one way to monitor the success of the goals of an educational institution, including Pesantren.

The presence of pesantren in providing education is expected to shape the character of the people into a superior generation. Pesantren's learning development is in line with the development of modernity and understanding that continues to grow (Yunus, 2019). Therefore, the learning curriculum in Pesantren will experience changes. The current condition appears in the public perception that religion and science are two different entities (Roji, 2019). Science does not care about religion, and religion does not care about science (Hidayati, 2017). This phenomenon makes the relationship between science and religion never harmonious (Munif, 2018).

Scientific integration is a combination of traditional (religious) education and modern (secular) education (Saihu, 2020). Efforts to eliminate the dichotomy of science (between spiritual and general knowledge) so that the goals of Islamic education can be achieved. All Islamic-based institutions must reflect that Islam is the source of all knowledge because the origin of knowledge is Allah SWT, which is poured into the Al-Quran and Sunnah/Hadith by the verse of the QS. Al-Baqarah verse 269;

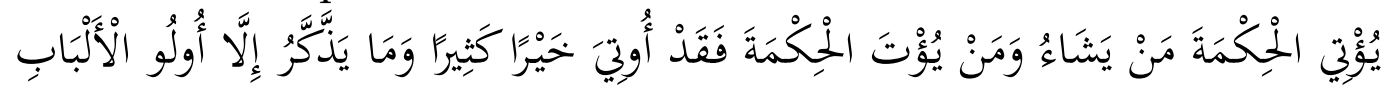

Meaning: "He gives wisdom to whom He wills, and whoever has been given wisdom has certainly been given much good. And none will remember except those of understanding."

The development of pesantren is currently an educational institution for parents with the hope that their children will become a generation with integrated IPTEK (science and technology) and IMTAK (Faith and Taqwa) to form personality traits that are obedient to God. The implementation of this integrated curriculum requires monitoring and evaluation regularly to measure the extent to which the expected educational goals have been achieved.

Wulandari (2020), in his research, said that the integration of the pesantren curriculum into the 2013 curriculum in schools was carried out through the addition of Islamic boarding school material in its subjects. Kusnandi (2017) said that integrating the curriculum is a form of school concern to form students who have the soul and morality. Munjiat (2017) states that in combining the curriculum between pesantren and schools, it is necessary to pay attention to aspects of the environment, human resources, and culture.

Huda (2017) stated that the management of curriculum development from an Islamic education perspective is a process or system of curriculum management in a cooperative, comprehensive, systemic, and systematic (holistic) manner, which refers to the achievement of educational goals in the 
curriculum, so there needs to be an evaluation to monitor improvements and improvements to the curriculum.

This is the research basis to determine the extent to which the implementation of scientific integration in the learning curriculum in Pesantren or Monitoring and Evaluation of the Implementation of the concept of scientific integration in the learning curriculum at the Baitul Fikri Modern Pesantren in Bandung. This research was conducted at the Baitul Fikri Pesantren in Bandung, which has an educational goal of "Students that can practice Islamic values in their daily lives" and has the concept of implementing the integration of religious knowledge in general sciences and technology in its curriculum.

\section{RESEARCH METHODS}

The research was conducted using a qualitative method (Qualitative analysis) to describe and analyze a process. This research was developed through the CIPO (Context, Input, Process, Output) evaluation technique (Scheerens, Glas, \& Thomas (2003).

This research was conducted at Baitul Fikri Modern Pesantren, Bandung, having its address at Jalan Terusan Pesantren, Arcamanik, Bandung City. Participants in this study include; the head of the foundation, the head of the pesantren, the vice head of the curriculum, several teachers, and 30 students. The data collection technique used is using structured interviews with a ratingscale or measuring attitudes and respondents' perceptions regarding the application of scientific integration to all students in Pesantren. In addition, observations of learning activities were also carried out, accompanied by recording observations of documentary studies by collecting and analyzing curriculum draft documents and Planning and Learning Plans from each subject teacher.

The data analysis technique used is Creswell analysis (2015); researchers read all data obtained from direct observation, structured interviews, and documentary data which are then combined with analysis according to Miles and Huberman (2014) with data reduction, data display, and conclusion drawing.

\section{RESULTS AND DISCUSSION \\ Context Component}

Baitul Fikri Modern Pesantren is a Pesantren if it is classified in the Modern Pesantren category, which organizes classic books/yellow books and learns several materials as in schools in general, with the holding of IT SMP which is still in one unit with the Pesantren - coupled with material skills such as entrepreneurship and environmental development programs.

The vision that is the hope of the Baitul Fikri Pesantren is, "To create a generation that is strong, has monotheism and has a noble character." One of its missions is, "Implementing integrated guidance between pesantren activities and school activities," so that the educational goals of the Baitul Fikri Modern Pesantren are written "To produce students who can practice Islamic values in their daily lives," which then concluded by the Deputy Head of the Curriculum during the interview is the application of scientific integration, combining 
general science and religious knowledge in the learning process so that it becomes a typical curriculum in Pesantren. The Baitul Fikri Modern Pesantren curriculum is divided into academic education and pesantren programs, selfdevelopment, and habituation activities.

General Education Covers PKN/Citizenship, Mathematics, Indonesian Language, English Language, Science, PJOK, Social Studies, PAI, Mulok/Local Lesson and SBK/cultural Arts and skills as well as Pesantren Programs including Classical Books / Yellow Books, Aqidah, Morals, Quran and Hadith, Islamic Fiqh and SKI.

Self-development programs include Muhadhoroh (Speech Practice), Tahsin and Tahfidz Qur'an), English and Arabic conversation, Scouting, Archery, Sports, Martial Arts, Scientific Writing, Calligraphy, Entrepreneurship, Introduction to IT, Public Speaking, Theater, and Islamic art.

The third is the habituation program. An Islamic character education program that will shape the life culture of the Pesantren, such as obligatory and sunnah worship activities including dzikr, wirid and prayer, akhlaqul karimah, sincerity, ukhuwah Islamiah, and independence, insaniyah, discipline, simplicity, leadership, and courage.

Monitoring and evaluation is an action or activity to measure value so that quality and results can be known (Jauhari et al., 2017; Hidayah, 2018; Mahmud \& Suratman, 2019). The monitoring and evaluation in the application of scientific integration is the academic education curriculum which will be studied more deeply with observation guidelines from monitoring during learning and from the existing syllabus documentary studies of each academic education subject at the Baitul Fikri Modern Pesantren.

The evaluation process is a process that compares the plan and implementation, which will result in a description or judgment. For the improvement of the implemented program, the overall results are needed. The evaluation objects include; inputs, processes, and results achieved/outputs (Susilana, 2006).

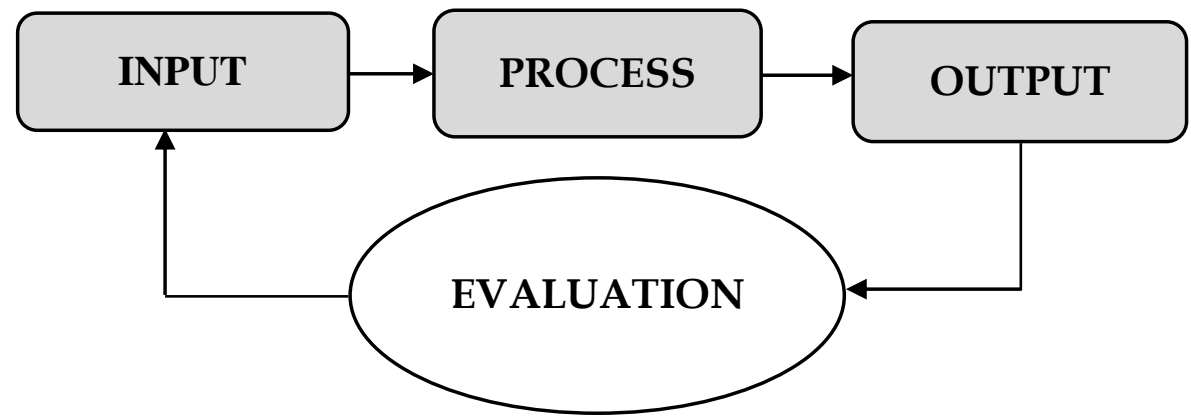

Figure 1: The Evaluation Process

In line with the views of Frederick Betz regarding Systems Paradigm, "all the disciplines of science and engineering, the concept of a "system" basically means to look at a "thing," with a view in seeing the thing as a "dynamic totality." A "dynamic totality" displays; 1) an internal "change"; and, 2) interacts with an "environment." A 'system' is a dynamical object which can be defined 
as; 1 ) an entity; 2) composed of a complex structure; 3) performing a process; 4) which is controlled; and 5) operating within an environment" (Betz, 2011).

That in all disciplines of science and engineering, the concept of "system" basically means looking at the "thing," with an inner view of seeing the thing as a "dynamic totality." "Dynamic totality" displays; 1) internal "change"; and 2) interaction with the "environment." A 'system' is a dynamic object that can be defined as; 1) an entity; 2) consisting of a complex structure; 3) performing processes; 4) being controlled, and 5) operating in an environment.

It can be known that to analyze a paradigm system from Scientific Integration, it is necessary to have Input - Process (as a System) - Output to obtain feedback from the achievement of the application of the paradigm. Using a documentary study by collecting one of the RPP/Learning Implementation Plans, which are guidelines for designing activities from the curriculum reference, observation guidelines using an attitude scale, and collecting valuable data resulting from learning.

\section{Input Component}

Various data on the implementation of learning plans that researchers got from teachers when delivering some lessons which usually became polemics for the dichotomy of science, were as follows; In the initial activity of Civics/Citizenship lessons class VII, the teacher explained the importance of studying Islam and social behavior QS. Az-Zukhruf verse 32 on the topic of Norms in Social Life. In the Mathematics Lessons Class VIII, the teacher gives the closing part of learning the material for a two-variable linear equation system by explaining the importance of understanding Mathematics, where the Quran is also taught about calculations, such as QS. An-Nisa verse 12 about the analysis of Marwaris. At the time of Indonesian Lesson Class VIII, the teacher begins the activity by praying, tadarus verses of the Koran regarding the natural phenomenon of QS. Ar-Ruum verse 41, read Asmaul Husna, before identifying information from the explanatory text in the form of exposure to an event of a natural phenomenon. In English Lesson Class VIII, students observe the material about recount text by first explaining the importance of learning the language according to the letter Qs. Al Hujurat: 13.

During the IPA lesson, the teacher conveys the motivation about what can be obtained (objectives \& benefits) by studying the Organization of Life System material and discussing the QS. An-Nuur verse 45 about Protozoa. At the time Social Studies Lessons Class VIII, the teacher provides a group learning regarding maritime economic activities by first explaining the explanation of QS, An-Nahl verse 14, and the teacher gives an explanation of the motivation for healthy living in the style of the Prophet Muhammad SAW, then gives a reflection on the activities of games that are concluded addressing cleanliness and health in life at home and in Pesantrens when student learn about physical education lessons class VII.

The results of the analysis that the researchers received from the data on the implementation of learning activities for general subject teachers at the Baitul Fikri Modern Pesantren showed that there is documentary data as an 
application of scientific integration with indicators of method integration and the linkage of the theory of verses that are practiced or discussed in general science through the story of Islamic history and there is a link between available science and a religious science. Irawan (2019) stated that the Islamic education curriculum does not dichotomize knowledge in line with the expert's statement.

\section{Components Process}

In the process analysis, the researcher used a rating-scale list reference from the six characteristics of Islamic education methods, according to Syaibani (1979). One is the integration of techniques, strategies and objectives, tools, and the spirit of the teachings and noble character of Islam, two applications that are flexible, meaning that they can be changed or conditioned according to the circumstances and atmosphere of both students, teachers and their environment, three, there is seriousness in linking between a theory with practice, learning process and practice, history and understanding, memorization and understanding, imla' and ijtihad, as well as encouraging the creativity and thinking ability of teachers and students, four reflecting scientific values, five emphasizing on the freedom of students to express opinions with correct evidence to strengthen the students' stance and six raise the teacher value so that they become good and noble characters.

Table 1: Accumulated Answers on 30 Respondents

\begin{tabular}{|c|c|c|c|c|c|c|c|}
\hline$\frac{\text { No }}{\text { Rep. }}$ & PKN/Citizenship & Math & Ind & Eng & Science & Social & PE \\
\hline 1 & 20 & 13 & 16 & 14 & 14 & 14 & 17 \\
\hline 2 & 19 & 15 & 19 & 17 & 14 & 18 & 20 \\
\hline 3 & 16 & 15 & 18 & 18 & 14 & 18 & 21 \\
\hline 4 & 18 & 15 & 20 & 20 & 17 & 19 & 21 \\
\hline 5 & 16 & 16 & 20 & 15 & 14 & 18 & 18 \\
\hline 6 & 20 & 13 & 20 & 18 & 18 & 16 & 20 \\
\hline 7 & 15 & 13 & 18 & 15 & 14 & 15 & 16 \\
\hline 8 & 18 & 16 & 19 & 17 & 14 & 17 & 20 \\
\hline 9 & 18 & 14 & 13 & 17 & 13 & 15 & 19 \\
\hline 10 & 15 & 9 & 16 & 15 & 16 & 16 & 18 \\
\hline 11 & 17 & 13 & 17 & 15 & 15 & 15 & 18 \\
\hline 12 & 13 & 10 & 16 & 12 & 12 & 17 & 19 \\
\hline 13 & 16 & 13 & 18 & 14 & 14 & 14 & 18 \\
\hline 14 & 17 & 13 & 15 & 14 & 15 & 16 & 16 \\
\hline 15 & 15 & 11 & 14 & 15 & 15 & 16 & 18 \\
\hline 16 & 20 & 13 & 16 & 14 & 14 & 14 & 17 \\
\hline 17 & 19 & 15 & 19 & 17 & 14 & 14 & 20 \\
\hline 18 & 16 & 15 & 18 & 18 & 14 & 18 & 21 \\
\hline 19 & 18 & 15 & 20 & 20 & 17 & 18 & 21 \\
\hline 20 & 16 & 16 & 20 & 15 & 14 & 19 & 18 \\
\hline 21 & 20 & 13 & 20 & 18 & 18 & 18 & 20 \\
\hline 22 & 15 & 13 & 18 & 15 & 14 & 16 & 16 \\
\hline
\end{tabular}




\begin{tabular}{cccccccc}
\hline 23 & 18 & 16 & 19 & 17 & 14 & 15 & 20 \\
\hline 24 & 18 & 14 & 13 & 17 & 13 & 17 & 19 \\
\hline 25 & 15 & 9 & 16 & 15 & 16 & 15 & 18 \\
\hline 26 & 17 & 13 & 17 & 15 & 15 & 16 & 18 \\
\hline 27 & 13 & 10 & 16 & 12 & 12 & 15 & 19 \\
\hline 28 & 16 & 13 & 18 & 14 & 14 & 17 & 18 \\
\hline 29 & 17 & 13 & 15 & 14 & 15 & 14 & 16 \\
\hline 30 & 15 & 11 & 14 & 15 & 15 & 16 & 18 \\
\hline TOTAL & 506 & 398 & 518 & 472 & 438 & 486 & 558 \\
\hline
\end{tabular}

The table 1 above showed that the Islamic education method provided by each subject teacher is not the same portion in implementing the scientific integration curriculum. It is evident from the results of the scores obtained in the table.

The highest number of general criteria scores (if each item gets the highest score) $=4 \times 6 \times 30=720$. For this, the highest score is 4 , the number of indicators on the rating scale $=6$, and the number of respondents $=30$.

\begin{tabular}{|c|c|c|}
\hline 30 & 360 & 480 \\
\hline done & Rarely done & Often done \\
\hline
\end{tabular}

The total score of data collection results in PKN/Citizenship/Citizenship Subjects $=506$. Thus, the application of scientific integration in PKN/Citizenship/Citizenship subjects according to the perception of 30 respondents was 506: $720=70 \%$. It is included in the category where the application of scientific integration is often carried out.

The total score of data collection results in Mathematics Subjects $=398$. Thus, the application of scientific integration in Mathematics subjects according to the perception of 30 respondents was 398: $720=55 \%$, included in the interval category rarely done and often done, close to seldom done.

In the total score of data collection results in subjects B.Indonesia $=518$. Thus, the application of scientific integration in subjects B.Indonesia according to the perception of 30 respondents was 518: $720=71 \%$, included in the interval category is often done.

In the total score of data collection results in Subject B. English $=472$. Thus the application of scientific integration in subjects B. English according to the perception of 30 respondents was 472 : $720=65 \%$, included in the category of intervals rarely done and often done, approaching to often done.

In the total score of data collection results in science subjects $=438$. Thus, the application of scientific integration in science subjects according to the perception of 30 respondents was 438: $720=60 \%$, included in the interval category rarely done and often done, approaching to often done. 
The total score of data collection results in Social Studies Subjects $=486$. Thus, the application of scientific integration in Social Studies subjects according to the perception of 30 respondents was 486: $720=67 \%$, included in the category of intervals that are rarely done and often done, close to often done.

The total score of data collection results in PJOK Subjects $=558$. Thus, the application of scientific integration in PJOK subjects according to the perception of 30 respondents was 558: $720=77 \%$, included in the category of intervals close to always being carried out.

Thus, it can be concluded that the research results on the analysis of the learning process and the application of scientific integration have been applied. However, some subjects still need to be improved.

\section{Output Component}

The main goal of an educational institution is to produce quality graduates. Article 2 of Law Number 20 of 2003 concerning the National Education System explains the function of national education, which must improve and shape the character that makes a civilized nation, dignified and intellectual. It also has a goal to develop the potential of students to become human beings who believe and fear God Almighty, has a noble character, are healthy, knowledgeable, capable, creative, independent, and become democratic and responsible citizens. National education standards article 25 paragraph 4 states that graduate competency standards include attitudes, knowledge, and skills (Fadhli, 2017).

There are two evaluation processes, namely formative and summative evaluation. Formative evaluation is an evaluation process that aims to improve or perfect the program. At the same time, summative evaluation is more about measuring results to assess whether the program has been effective and efficient or not (Sukmadinata, 2010). The researchers also took documentary data from summative learning outcomes from subjects with the lowest and highest integration results based on the findings obtained.

From the results of the value data obtained from the Physical Education lesson summatively, the average score of 81 was obtained with the criteria of three aspects of measurement, cognitive, affective, and psychomotor students. While in mathematics, the average summative score of students is 73.

It can be concluded that subjects where the application of integration is often carried out, such as the habituation of the teacher to say greetings at the beginning and the end of the meeting as an example of the teacher's role model for students, providing explanations related to the verses of Kauniyah and Kauliyah Allah SWT, giving tasks that his people understand. The implementation of discussion methods or appropriate methods so that there is a communication link that brings the teacher closer to the students, as well as habituation and motivation that shape the character of the students' personality, resulted in significant results with the average effect of the summative test for Physical Education subjects from the 30 respondents was 81. In Mathematics subjects whose application was rarely carried out, the summative results were 
obtained with an average of 73. Researchers got new findings; the more often the implementation of scientific integration is done, the more it will affect student achievement.

\section{CONCLUSION}

Monitoring and evaluation of the results of the application of scientific integration in the learning curriculum obtained from the analysis of input data when observing students' learning activities and from the documentary RPP data, it can be concluded that the implementation of the integration of science planned by the teacher in the lesson plans has been implemented. However, the intensity of the integration is done consistently. Some are still not consistent. The percentage analysis in the implementation process that takes place is $70 \%$ in PKN/Citizenship/Citizenship subjects, 55\% in Mathematics, $71 \%$ in Indonesian B subjects, $65 \%$ in English B subjects, $60 \%$ in Science subjects, $67 \%$ in social studies subjects and $77 \%$ in PJOK subjects.

\section{REFERENCES}

Betz, F. (2011). Managing Science. London: Springer New York Dordrecht Heidelberg.

Creswell, W, J. (2015). Research Design. London: Sage Publication.

Fadhli, M. (2017). Manajemen Peningkatan Mutu Pendidikan. Tadbir: Jurnal Studi Manajemen Pendidikan, 1(2), 215-240.

Hidayah, U. (2018). Rekonstruksi Evaluasi Pendidikan Moral menuju Harmoni Sosial. Jurnal Pedagogik, 5(1), 69-81.

Hidayati, W. (2017). Manajemen Kurikulum Pendidikan Agama Islam dan Budi Pekerti Jenjang SMA Bermuatan Keilmuan Integrasi Interkoneksi. Manageria: Jurnal Manajemen Pendidikan Islam, 1(2), 195-225. https://doi.org/10.14421/manageria.2016.12-03

Huda, Nurul. (2017). Manajemen Mutu di Lembaga Pendidikan Islam. AlTanzim : Jurnal Manajemen Pendidikan Islam, 2(1),73-74.

Irawan. (2019). Filsafat Manajemen Pendidikan Islam. Bandung: Remaja Rosdakarya.

Jauhari, M., Rofiki, M., \& Farisi, Y. Al. (2017). Authentic Assessment dalam Sistem Evaluasi Pengembangan Kurikulum 2013. Pedagogik: Jurnal Pendidikan, 4(1), 103-116.

Kusnandi, K. (2017). Integrasi Kurikulum Berbasis Pesantren pada Lembaga Pendidikan. Jurnal Kependidikan, 5(2), 279-297.

Mahmud, M. E., \& Suratman, S. (2019). Evaluasi Program Manajemen Pembelajaran pada Sekolah Adiwiyata Kalimantan Timur. Al-Tanzim: Jurnal Manajemen Pendidikan Islam, 3(2), 85-96. https://doi.org/10.33650/al-tanzim.v3i2.691

Miles, M.B, Huberman, A.M, \& Saldana, J. (2014). Qualitative Data Analysis, A Methods Sourcebook. USA: Sage Publications. 
Munif, M. (2018). Perguruan Tinggi Berbasis Pesantren: Menggagas Interkoneksi Agama dan Sains. Jurnal Penelitian, 12(1), 137-160. https://doi.org/10.21043/jp.v12i1.4928.

Munjiat, S. M. (2017). Integrasi Kurikulum Pesantren dan Madrasah pada Pondok Pesantren Manba'ul 'Ulum Sindangmekar Dukupuntang Cirebon. Al-Tarbawi Al-Haditsah: Jurnal Pendidikan Islam, 2(2), 142-162

Rojii, M., Istikomah, I., Aulina, C. N., \& Fauji, I. (2019). Desain Kurikulum Sekolah Islam Terpadu (Studi Kasus di SMPIT Insan Kamil Sidoarjo). AlTanzim: Jurnal Manajemen Pendidikan Islam, 3(2), 49-60.

Saihu, S. (2020). Konsep Pembaharuan Pendidikan Islam Menurut Fazlurrahman. Andragogi: Jurnal Pendidikan Islam dan Manajemen Pendidikan Islam, 2(1), 82-95.

Scheerens, J., Glas, C., \& Thomas, S. M. (2003). Educational Evaluation, Assessment, and Monitoring: A Systemic Aproach. Lisse: Swets \& Zeitlinger B. V. Siradjudd

Wulandari, A. P. (2020). Integrasi Kurikulum Pesantren dalam Kurikulum 2013 Di SMK Al-Munawwir Krapyak Yogyakarta. Al-Fahim: Jurnal Manajemen Pendidikan Islam, 2(1), 20-34.

Yunus, Y., Mukhtar, J., \& Nugroho, I. (2019). Manajemen Pengembangan Pondok Pesantren (Studi Kasus di Pondok Pesantren As' adiyah Belawa Baru, Masamba, Sulawesi Selatan). Al-Tanzim: Jurnal Manajemen Pendidikan Islam, 3(1), 82-101. 